\title{
ŚRODOWISKOWE UWARUNKOWANIA PRZESTĘPCZOŚCI W BRYTYJSKICH BADANIACH KRYMINOLOGICZNYCH
}

Streszczenie: Przedmiotem analizy jest teoria międzypokoleniowej transmisji zachowań przestępczych. Karalność ojców odniesiona została do karalności ich synów oraz do psychospołecznych czynników ryzyka. W drugiej części artykułu omówiono teorię SAT (sytuacyjna teoria działania), która wyjaśnia, w jaki sposób interakcje pomiędzy jednostką i jej środowiskiem wpływają na przestrzeganie bądź łamanie norm dotyczących zachowania (zwłaszcza norm prawnych).

Słowa kluczowe: przestępczość nieletnich, karalność ojców, psychospołeczne czynniki ryzyka, transmisja międzygeneracyjna, sytuacyjna teoria działania (SAT).

\section{Wstęp}

Abstrahując od indywidualnych przypadków przestępstw, mających swoją etiologię w psychopatologii jednostki (psychopatyczni zabójcy, osoby z depresją popełniający samobójstwo rozszerzone itd.), największa część przestępstw ma genezę środowiskową, a nie biologiczną. W artykule zostaną zaprezentowane argumenty (teorie, poglądy, badania brytyjskie) na potwierdzenie tej tezy. Oczywiście, powiązanie czynników genetycznych i biologicznych, z jednej strony, oraz środowiskowych, z drugiej, przydarza się tak często, że trudno czasem oddzielić jedne predykatory od drugich ${ }^{1}$. Jednak to właśnie sytuacyjność ludzkiego zachowania oraz społeczny determinizm człowieka wysuwa się na plan pierwszy współczesnych dociekań kryminologicznych.

1 W obrazie przeciętnego przestępcy dostrzec można synergię czynników biologicznych i społecznych w etiologii przestępstwa. W końcu przeciętny przestępca to młody mężczyzna żyjący w dużym mieście - criminals are young urban males, zob. S. Walklate (2003, s. 34). 


\section{Cambridge Study in Delinquent Development}

Brytyjskie dane pochodzące $z$ badań longitudinalnych nad rozwojem przestępczości (Cambridge Study in Delinquent Development, tzw. CSDD) pokazują pewną przewagę czynników środowiskowych nad genetycznymi. Katherine M. Auty, David P. Farrington oraz Jeremy W. Coid, korzystając z badań CSDD, analizowali zjawisko transmisji międzygeneracyjnej (intergenerational transmission), czyli procesu transferu zachowań naruszających normy prawne od przestępczych rodziców (criminal parents) do ich dzieci, które również dopuszczają się łamania prawa (delinquents). Autorzy piszą, że za 59 proc. efektów transmisji międzypokoleniowej odpowiadają czynniki środowiskowe, zaś 41 proc. cech dzieci przypisać można czynnikom genetycznym (Auty i in. 2017, s. 217). W badaniach Thornberry'ego posiadanie chłodnej matki, na której nie można polegać, oraz ojca, który ma problemy finansowe i stosuje surową dyscyplinę, to sytuacja zwiększająca prawdopodobieństwo, że dzieci staną się przestępcami. Posiadanie antysocjalnej rodziny (antisocial family) naraża wzrastające w niej dzieci na pojawienie się zachowań przestępczych. Antysocjalność rodziny jest efektem przejmowania przez nią wzorów zachowania z poprzedzających ją pokoleń (cech zarówno odziedziczonych, jak i wyuczonych), ale również jest wynikiem działania czynników makrospołecznych, destrukcyjnego oddziaływania szerokiego kontekstu społecznego. Zamieszkiwanie w dzielnicach defaworyzowanych, bezrobocie, trudna sytuacja finansowa to dodatkowe czynniki wzmacniające destrukcyjne oddziaływanie rodziców na dzieci (rodzic przeżywający stres, nieprawidłowo używający substancji psychoaktywnych). Nieletni przestępca w okresie swojego dzieciństwa przejmuje od swoich rodziców ich bezradność wobec codziennych wyzwań, odwzorowuje słabe więzi prospołeczne, a następnie, już w okresie adolescencji, uczy się od swoich rówieśników zachowań antyspołecznych (Auty i in. 2017, s. 220-221; Bernasiewicz, Noszczyk-Bernasiewicz 2017).

CSDD objęły 411 mężczyzn pochodzących z południowego Londynu, urodzonych ok. 1953 roku (próbę określono jako G2). W badaniach wystąpiły jeszcze dwie populacje badawcze - G1, czyli rodzice osób z generacji G2 oraz G3, czyli synowie i córki osób z grupy badanej G2 (Auty i in. 2017, s. 217). Wśród wielu wniosków za szczególnie interesujące uznać należy te, które wskazują na predykatory przestępczości nieletnich, tj. przede wszystkim na siedem psychospołecznych czynników ryzyka (psychosocial risk factors). Wystąpiły one w populacji G2 (ojcowie dla populacji G3). Były to: problemy mieszkaniowe ojców (brak mieszkania własnościowego, więcej niż dwa adresy zamieszkania w ciągu ostatnich pięciu lat itd.), problemy wynikające z kohabitacji (trzy lub więcej takich związków, brak zawarcia związku małżeńskiego i pozostawanie w kohabitacji przez pięć lat bądź dłużej itd.), problemy z zatrudnieniem (trzy bądź więcej miejsc pracy w ciągu ostatnich pięciu lat, obecny brak zatrudnienia, przynależność do klasy niższej itd.), nadużywanie alkoholu oraz używanie narkotyków. Dalej udowodniono jeszcze kryminogenny wpływ stania się ojcem w wieku nastoletnim oraz posiadanie dużej rodziny (posiadanie 
czterech bądź większej liczby dzieci). Oprócz tych siedmiu sytuacji wyróżniono jeszcze trzy czynniki ryzyka, wykorzystując do tego dane pozyskane od populacji G3, czyli od dzieci z wcześniej badanej grupy. Za ważne środowiskowe predykatory przestępczości nieletnich uznano: rozbicie rodziny (ojciec opuścił rodzinę, zanim dziecko ukończyło 16 rok życia), surową dyscyplinę (bicie dzieci jako środek wychowawczy) oraz niewystarczającą kontrolę rodzicielską (rodzice nigdy nie wiedzieli, gdzie przebywa dziecko, gdy wychodzi z domu) (Auty i in. 2017, s. 223). Wszystkie wymienione czynniki ryzyka, wraz z karalnością ojców, okazały się być znaczącymi predykatorami zachowań przestępczych u dzieci.

W omawianych badaniach dowiedziono, że posiadanie rodziców, którzy zostali skazani za przestępstwo, w sposób istotny zwiększa prawdopodobieństwo wejścia $\mathrm{w}$ konflikt $\mathrm{z}$ prawem ich dzieci, ale również zwiększa prawdopodobieństwo doświadczania przez dzieci wielu psychospołecznych czynników ryzyka w dzieciństwie. W populacji G2 znalazło się 105 skazanych ojców (43,39 proc. badanej populacji). W populacji dzieci (G3) ujawniono 84 skazanych synów i córek (15,94 proc.). Skazanie ojca (ale również matki) zwiększało prawdopodobieństwo skazania syna (w mniejszym stopniu córki), ale generowało jednocześnie dodatkowy wpływ pośredni na pojawienie się konfliktu z prawem u dzieci w postaci wytworzenia niekorzystnego środowiska społecznego dla prawidłowej socjalizacji. Skazanie ojców w największym stopniu zwiększało prawdopodobieństwo pojawienia się $\mathrm{w}$ rodzinie problemów związanych $\mathrm{z}$ kohabitacją (cohabitation problems) - 11 razy większa szansa ich wystąpienia w porównaniu z rodzinami, w których skazanie ojców nie wystąpiło $(\mathrm{OR}=11.16$; iloraz szans=11.16, ang. odds ratio). Skazanie ojców zwiększało również prawdopodobieństwo problemów $\mathrm{z}$ używaniem przez dzieci narkotyków $(\mathrm{OR}=5.64)$ i alkoholu $(\mathrm{OR}=5.02)$, a także zwiększało szansę na rozpad rodziny $(\mathrm{OR}=4.52)$. Przy czym iloraz szans OR większy niż dwa uznaje się za wskaźnik silnego efektu działania określonej zmiennej w porównaniu do grupy porównawczej, w której ta zmienna jest nieobecna (Auty i in. 2017, s. 226).

Odnosząc się z kolei do populacji skazanych dzieci (G3), trzeba zauważyć różnice we wpływie psychospołecznych czynników ryzyka w zależności od płci. W przypadku chłopców skazanych za popełnienie przestępstwa najbardziej powiązane $\mathrm{z}$ ich skazaniem były następujące czynniki ryzyka dotykające ich ojców: używanie narkotyków, problemy mieszkaniowe, historia zatrudnienia, a także rozbicie rodziny oraz słaba kontrola rodzicielska. W przypadku dziewcząt bardziej znaczącymi predykatorami były: problemy związane z kohabitacją ojców, nadużywanie przez ojca alkoholu oraz surowy styl wychowawczy rodziców (Auty i in. 2017, s. 226). Rekapitulując, omawiane badania potwierdzają szerzej znaną tezę o związku karalności rodziców (zmienna niezależna) z karalnością ich dzieci (zmienna zależna). Ten bezpośredni związek (direct effect), jak ukazano, wzmacniany jest przez oddziaływanie psychospołecznych czynników ryzyka (indirect effect), które autorzy nazywają mediatorami zachowań przestępczych. Mediatory 
to zmienne pośredniczące, które wpływają na zmienną zależną, jaką w prezentowanych badaniach stanowią zachowania przestępcze (criminal behaviour) nieletnich ${ }^{2}$.

Schemat 1. Karalność rodzica (convicted parent) i mediatory w kryminogenezie

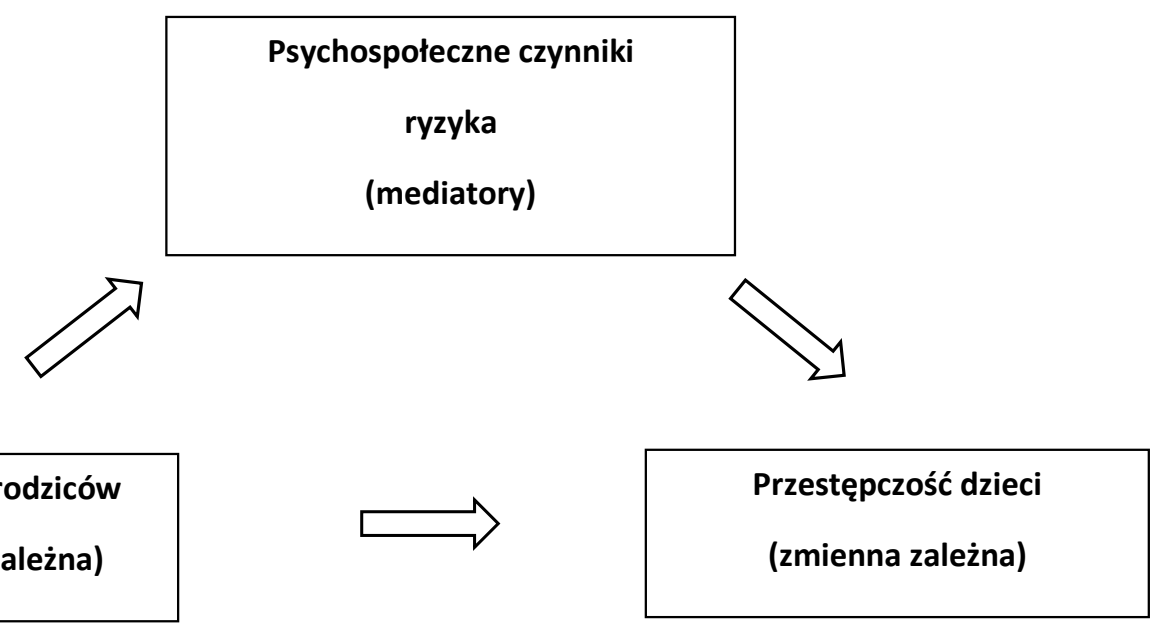

Źródło: Opracowanie własne na podstawie Auty i in. 2017, s. 224.

Zachowania przestępcze mogą być efektem modelowania, także tego zachodzącego w relacji rodzic-dziecko. Te i inne badania (por. M. Bernasiewicz, M. Noszczyk-Bernasiewicz 2017) pokazują jednak, że w relacji tej nie chodzi o proste przekazywanie technik przestępczych przez rodzica, który uczy swoje dziecko nielegalnych zachowań. Jest to bardziej złożony proces, w którym wejście przez rodzica w konflikt z prawem wywołuje efekt domina w jego rodzinie. Dorosły człowiek wraz z popełnieniem przestępstwa naraża siebie oraz swoją rodzinę na szereg napięć i konfliktów, które poza innymi konsekwencjami (rozpad rodziny, izolacja więzienna, uzależnienia, brak legalnej pracy itd.) mają i taki skutek, że generują zachowania przestępcze w życiu dzieci. W rodzinach przestępczych dzieci doświadczają braku należytej kontroli i uwagi wychowawczej, przemocy, narażone są na uzależnienia itd., co w istocie zapośrednicza wejście przez nie w konflikt z prawem. Przy czym dla dziewcząt najsilniejszym predykatorem dla zachowań przestępczych w sytuacji karalności rodziców są niestabilne warunki życia rodzinnego oraz despotyczny styl wychowawczy (an unstable home, punitive discipline), zaś dla chłopców brak kontroli rodzicielskiej (Auty i in. 2017, s. 229-230). Dlatego pisze się czasem, że męska przestępczość wywodzi się z wpływu świata zewnętrznego,

${ }^{2} \mathrm{~W}$ odróżnieniu od mediatorów (mediator variables), które są skutkiem wystąpienia zmiennej niezależnej, bądź po prostu następują po niej, występują jeszcze moderatory (moderator variables), które poprzedzają zmienną niezależną i podobnie jak mediatory wpływają na kierunek i siłę oddziaływania zmiennej niezależnej na zmienną zależną (Auty i in. 2017, s. 216). 
zaś żeńska - z wnętrza rodziny. Tak czy inaczej rodzice kreują zachowania swoich dzieci poprzez warunki, jakie im stwarzają.

\section{Situational Action Theory (SAT)}

Teorią integrującą perspektywę indywidualną ze środowiskową w badaniach nad przestępczością jest Situational Action Theory (SAT), czyli teoria sytuacyjności działań społecznych. SAT jest ogólną teorią przestępstwa (act of crime) uwzględniającą różnorodność oraz wzajemne interakcje pomiędzy licznymi przyczynami aktu przestępczego. W teorii tej uznaje się wagę zarówno predykatorów jednostkowych (person's propensity; person-oriented), jak i środowiskowych (exposure to criminogenic settings; environment-oriented). SAT uwzględnia wszystkie przyczyny przestępstwa w ich wzajemnych interakcjach (person-setting interactions) - poczynając od tych najbardziej szerokich (causes of the causes), które pomagają uchwycić podejście ekologiczne, przez przyczyny związane z najbliższym otoczeniem, aż po jednostkowe skłonności przestępcy (Wikström i in. 2013, s. 1-10). Ludzie, wedle tej teorii, są sprawcami działań społecznych. Przy czym z punktu widzenia kryminologii najważniejsze są te działania, które są zachowaniami podporządkowującymi się lub naruszającymi normy prawne. Przestępcy są aktywnymi aktorami społecznymi, ponieważ informacje, jakie uzyskują na początku swojej działalność przestępczej, zależne od środowiska, w którym żyją, służą im za materiał do podjęcia decyzji o kierunku swojego zachowania (perception-choice process). Ta bliska perspektywie kognitywizmu teoria bierze pod uwagę trzy elementy konstytutywne dla każdego zachowania ludzkiego. Rozpatrując ludzkie zachowanie, mamy zawsze do czynienia $\mathrm{z}$ aktorem społecznym (podmiotem), po drugie $-\mathrm{z}$ kontekstem działania (action contexs) oraz po trzecie - $\mathrm{z}$ interakcjami pomiędzy nimi (interakcje zależą także od szerokiego kontekstu społecznego) (Wikström i in. 2013, s. 10). W modelu SAT, za którego twórcę uchodzi Per-Olof H. Wikström - równie ważne są zarówno skłonności osobiste (samokontrola, odporność na sytuację pokusy czy prowokację), jak i kryminogenne cechy otoczenia społecznego (np. obecność bądź brak egzekucji prawa).

SAT zachowuje swoją moc eksplanacyjną - podług swojego twórcy - w każdym miejscu i czasie, ponieważ jest teorią zachowań moralnych (teorią tego, co ludzie uważają za zachowanie moralnie złe bądź dobre). Wikström rozpatruje sam fakt respektowania bądź łamania przez jednostkę reguł społecznych, a nie niezgodność zachowania z konkretną normą prawną, gdyż ta podlega zmienności zarówno w czasie, jak i przestrzeni. Innymi słowy, SAT nie rozstrzyga, co jest normą obiektywną; nie stara się wyjaśnić, dlaczego ludzie wchodzą w konflikt z uniwersalnym światem ludzkich norm (dlaczego wchodzą w konflikt z prawem). W teorii tej chodzi raczej o zrozumienie mechanizmu działania bądź niedziałania reguł moralnych (w tym prawa) w życiu konkretnych ludzi. Nawet uszanowanie przed dwoje ludzi tej samej normy moralnej nie oznacza jeszcze, że pełni ona w ich 
życiu tę samą rolę. Ludzie różnią się od siebie poziomem wstydu oraz poczucia winy z powodu naruszenia uznanej przez siebie normy. Wikström podaje m.in. przykład powszechnego uznania za naganne przechodzenia przez ulicę na czerwonym świetle. Nie przeszkadza to jednak wielu ludziom łamać tę normę, ponieważ uważają takie wykroczenie za sprawę małej wagi. Polska tradycja kryminologiczna, za Adamem Podgóreckim, dzieli sondowane poglądy respondentów na wartości uznawane (deklarowane) przez jednostkę - np. ujawnienie przez respondenta, że „przechodzenie na czerwonym świetle jest naganne” - oraz wartości odczuwane (praktykowane), kiedy ten sam respondent ujawnia jednocześnie: „jak się bardzo spieszę, to czasem przechodzę na czerwonym świetle”. Powyższe rozróżnienie na wartości deklarowane i uznawane obecne jest w teorii SAT pod postacią wartości moralnych (działania uznane przez jednostkę za złe bądź dobre - moral values) oraz moralnych emocji (wskazują na siłę poszczególnej normy moralnej - moral emotions) ( Wikström i in. 2013, s. 14).

Istotą teorii SAT jest sytuacyjność ludzkiego zachowania, która oznacza proces rozpatrywania przez jednostkę możliwych zachowań alternatywnych i podejmowanie decyzji w oparciu o dynamicznie zachodzącą interakcję pomiędzy zachowaniem jednostki (action) a otoczeniem, w którym się znalazła (setting). Na ludzkie otoczenie składają się obiekty, ludzie, wydarzenia (Wikström i in. 2013, s. 15). Zarówno predykatory środowiskowe, jak i indywidualne aktualizują się w określonych sytuacjach i skutkują określonym zachowaniem jednostki. Inaczej można jeszcze powiedzieć, że jednostka w procesie podejmowania decyzji (perception-choice proces) jest orientowana przez czynniki sytuacyjne, które w teorii SAT sprowadzono do 1) motywacji; 2) filtru moralnego oraz 3) systemu kontroli (Wikström i in. 2013, s. 22-28). Ich działanie jest silnie splecione z jednostkowymi predyspozycjami (tj. siła potrzeb, podatność na sytuację pokusy, bycie pod wpływem działania środków psychoaktywnych).

Jeśli chodzi o pierwszy czynnik sytuacyjny (zob. schemat 2), czyli motywację do zachowań przestępczych, to według SAT dwoma głównymi motywatorami są pokusy (temptations) oraz prowokacje (provocations). Pokusa związana jest ściśle z potrzebami jednostki i towarzyszy jej często szereg pozytywnych emocji (ekscytacji, radości, satysfakcji), podczas gdy prowokacje, jako wynik czyjejś ingerencji wywołującej w jednostce złość i agresję, są bodźcem wyzwalającym emocje negatywne. Zarówno pokusy, jak i prowokacje mogą prowadzić do zachowań przestępczych. Warto zauważyć polemiczny charakter SAT wobec ogólnej teorii napięcia Agnew, w której akt przestępczy wyłania się jedynie z negatywnych emocji powodowanych przez napięcia i stresory. W SAT podkreśla się, że łamanie norm społecznych nie mniej często powiązane jest z emocjami pozytywnymi generowanymi w sytuacjach pokusy (Wikström i in. 2013, s. 24). Filtr moralny to kolejny czynnik sytuacyjny, który jest istotny z punktu widzenia reakcji jednostki na zaistnienie sytuacji pokusy bądź prowokacji. Uległość jednostki wobec pokusy/ prowokacji zależna jest od tego, jakich sądów moralnych dokona ona w sytuacji 
próby. Owe sądy moralne (filtr moralny) to efekt interakcji zachodzącej pomiędzy moralnością jednostki (wartości moralne jednostki oraz emocje z nimi związane) a moralnością otoczenia (postrzegane przez jednostkę reguły, jakimi kieruje się jej otoczenie społeczne) (interaction between personal morality and moral norms of the setting). Wynik konfrontacji moralności jednostki z moralnością jej otoczenia będzie wpływał na jej motywację do zachowania zgodnego bądź sprzecznego z ładem prawnym. Przy czym, jeśli w którymkolwiek systemie normatywnym (osobistym czy społecznym) przestępstwo nie jest dopuszczalne (nie jest zachowaniem alternatywnym), to z oczywistych względów do przestępstwa nie dojdzie (poza sytuacją przestępczości z przypadku) (zob. schemat 2). Ostatnim czynnikiem sytuacyjnym, który ma kluczowe znaczenie dla podjęcia zachowania przestępczego, jest system kontroli (controls). Czynnik ten odgrywa efektywną rolę w dwóch sytuacjach. Po pierwsze, kontrola społeczna okazuje się istotna w sytuacji, gdy jednostka dokonuje kalkulacji przestępstwa, a zatem nie popełnia go w sposób instynktowny, nawykowy, lecz rozważa jego racjonalność. Po drugie, kontrola społeczna ma znaczenie wówczas, gdy zachodzi konflikt pomiędzy moralnością jednostki a regułami, które narzuca jej otoczenie.

Schemat 2. Rola filtra moralnego oraz systemu kontroli w kryminogenezie

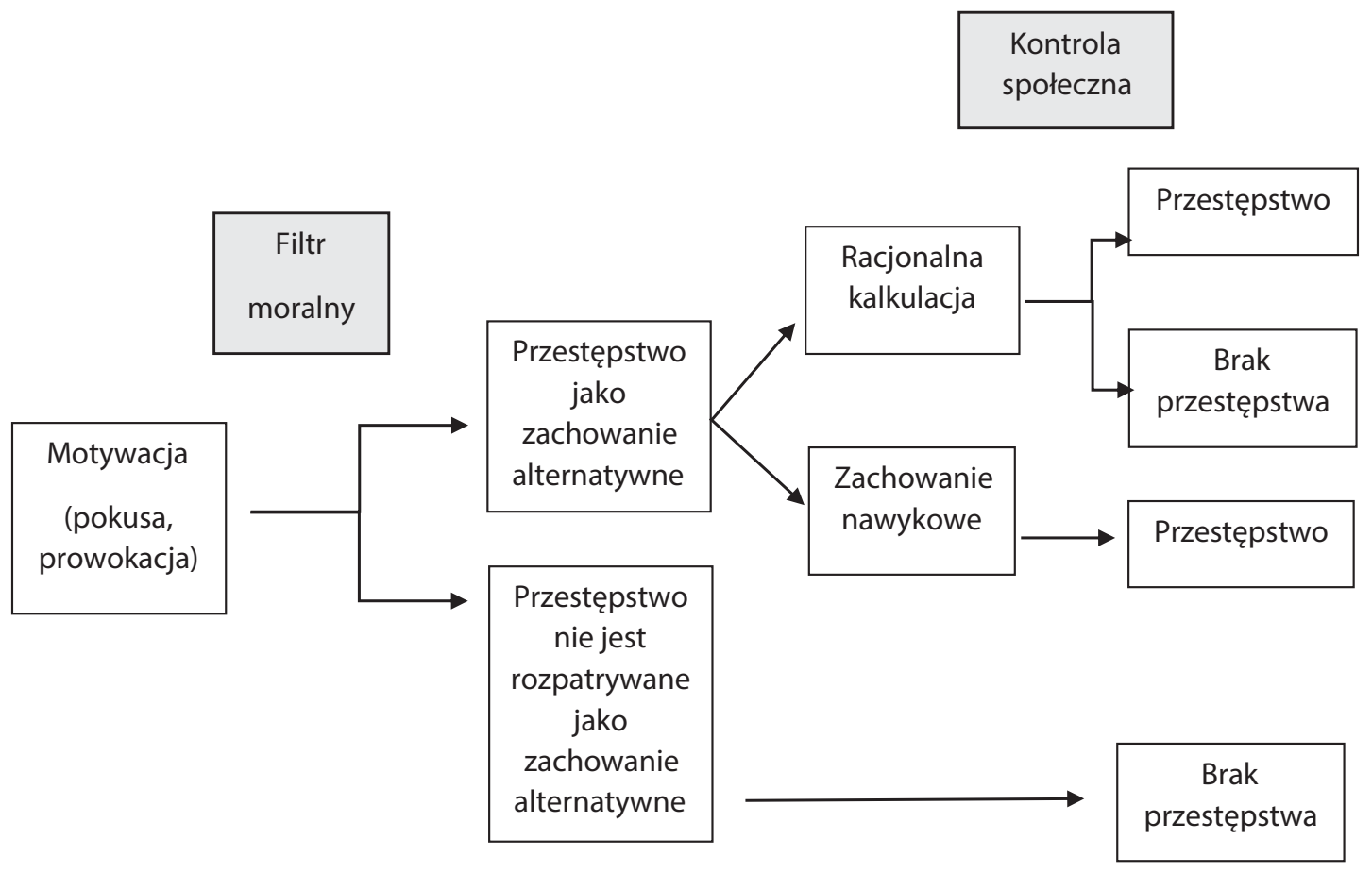

Źródło: Opracowanie własne na podstawie Wikström i in. 2013, s. 29.

Kontrola społeczna może być pochodzenia wewnętrznego (samokontrola) oraz zewnętrznego (system odstraszania). W pierwszym przypadku (proces odśrodkowy) 
jednostka przestrzega własne zasady moralne, odrzucając moralność otoczenia (np. odmawia udziału w przestępstwie, do którego zachęca ją grupa rówieśnicza). W drugim przypadku (proces dośrodkowy) zachodzi wymuszenie dostosowania się do norm wspólnotowych poprzez skuteczne wzbudzenie lęku przed konsekwencjami ich złamania. Efektywne wzbudzenie lęku przed naruszeniem prawa skłania jednostkę do przestrzegania norm otoczenia, pomimo faktu, iż pozostają one w konflikcie z moralnością jednostki (Wikström i in. 2013, s. 25-26). W opisywanym procesie podejmowania decyzji zapoczątkowującej działanie społeczne o naturze przestępczej jednostka wciąż negocjuje pomiędzy argumentami wysuwanymi przez własne potrzeby (czasem działa w sposób nawykowy) a normami obowiązującymi w społeczności, pomiędzy racją wartości własnych a presją wartości kolektywnych, pomiędzy chęcią podjęcia określonego zachowania a spodziewanymi konsekwencjami tej decyzji. Na różnych etapach tego procesu akt przestępczy jawi się jako zachowanie alternatywne, które zostaje podjęte w bardziej bądź mniej świadomy sposób (na skutek braku właściwej kontroli społecznej czy obecności w jednostce silnych nawyków przestępczych, jak to ma miejsce w sytuacji przestępców niepoprawialnych, zob. Zalewski $2010^{3}$ ), albo zostaje odrzucone (konformizm). W przedstawionym modelu istnieje także miejsce dla osób (schemat 2), które nie postrzegają przestępstwa jako zachowania alternatywnego. Wobec nich można powiedzieć, że nie są podatne na przestępstwo (ani ich osobisty system moralny, ani moralność wspólnotowa nie dopuszcza takiej alternatywy).

\section{Zakończenie}

Środowiskowa proweniencja przestępczości nieletnich nie wyklucza znaczenia cech jednostkowych, które czynią daną jednostkę podatną bądź niepodatną na kryminogenne oddziaływanie środowiska. Zwłaszcza płeć jest zmienną, która różnicuje efekt oddziaływania tego samego otoczenia społecznego. Dominacja mężczyzn w ogólnej populacji przestępców bierze się także z tego, że dziewczęta okazują się bardziej odporne na oddziaływanie niekorzystnego środowiska. Chłopcy są bardziej wrażliwi na psychospołeczne czynniki ryzyka niż dziewczęta, które posiadają wyższy próg odporności (girls have to pass a higher critical „risk level” in order to become delinquent) (Auty i in. 2017, s. 229). Rolę zasobów indywidualnych (w tym biologicznych) podkreśla się m.in. w koncepcji resilience, która identyfikuje te zasoby jednostki, które chronią ją przed niekorzystnym wpływem czynników ryzyka. Pozytywna adaptacja jednostki pomimo występujących zagrożeń możliwa

${ }^{3}$ Doskonała publikacja Wojciecha Zalewskiego o przestępcach „niepoprawnych” (niem. unverbesserliche, ang. incorrigible) operuje - już w ty tule - terminem używanym w Polsce w międzywojniu (1918-1939) na określenie „przestępcy zawodowego”, „przestępcy z nawyknienia”. Wydaje się, że dziś należałoby mówić raczej o „przestępcy niepoprawialnym”. Można by także użyć pojęcia "przestępcy niewychowalnego" lub „nieuleczalnego”. 
jest dzięki posiadanym przez nią zasobom środowiskowym (np. pomimo skazania ojca, matka może być osobą silnie wspierającą rozwój dziecka) oraz zasobom jednostkowym (wysoka inteligencja, empatia, adekwatne poczucie własnej wartości czy też wysoki poziom aspiracji itp.) (por. Wysocka, 2015, s. 42-45). Opisane w tekście teorie transmisji międzygeneracyjnej oraz SAT wskazują na szereg istotnych środowiskowych determinantów przestępczości nieletnich. Nie będzie może nadmierną redukcją, jeśli wskażę na dwa, najważniejsze obszary, które wydedukować można $\mathrm{z}$ opisanych teorii. Z punktu widzenia prewencji przestępczości najważniejszym obszarem będzie stwarzanie optymalnych warunków do życia rodzinnego (teoria transmisji międzygeneracyjnej) oraz zainstalowanie $w$ jednostce (w procesie interioryzacji) oraz $\mathrm{w}$ jej środowisku właściwych mechanizmów kontroli społecznej (SAT). Z tak wytyczonych celów profilaktyki przestępczości wyprowadzić można dwie procedury ich wdrożenia, tj. rozbudowę systemu wsparcia społecznego antysocjalnych rodzin (antisocial family) oraz stałą poprawę egzekucji prawa (szybkie i efektywne reagowanie na przejawy demoralizacji i przestępczości, najlepiej realizowane w modelu sprawiedliwości naprawczej - restorative justice) (Por. Hudson, 2003, s. 75-92).

\section{Bibliografia}

Auty K. M., Farrington D. P., Coid J. W. (2017). The Intergenerational Transmission of Criminal Offending: Exploring Gender-specyfic Mechanisms. „The British Journal of Criminology", nr 57, s. 215-237.

Bernasiewicz M., Noszczyk-Bernasiewicz M. (2017). Family Life and Crime. Contemporary Research and Essays. Katowice: Wydawnictwo Uniwersytetu Śląskiego (w druku).

Hudson B. A. (2003). Understanding justice. An introduction to ideas, perspectives and controversies in modern penal theory. Berkshire: Open University Press.

Walklade S. (2003). Understanding criminology. Current theoretical debates. Maidenhead: Open University Press.

Wikström P-O. H., Oberwittler D., Treiber K., Hardie B. (2013). Breaking Rules. The Social and Situational Dynamics of Young People's Urban Crime. Oxford: Oxford University Press.

Wysocka E. (2015). Diagnoza pozytywna w resocjalizacji. Model teoretyczny i metodologiczny. Katowice: Wydawnictwo Uniwersytetu Śląskiego.

Zalewski W. (2010). Przestępca niepoprawny - jako problem polityki kryminalnej. Gdańsk: Wydawnictwo Arche. 


\title{
ENVIRONMENTAL FACTORS OF CRIME IN BRITISH CRIMINOLOGICAL STUDIES
}

\begin{abstract}
This study presents the theory of intergenerational transmission of criminal behaviour. The conviction of fathers is related to the convictions of their male offspring and to the psychosocial risk factors. In the second part of the article SAT (Situational Action Theory) is described. SAT explains how person-setting interactions influence people to follow or breach rules of conduct (stated in law).
\end{abstract}

Keywords: delinquency, convictions of fathers, psychosocial risk factors, intergenerational transmission, Situational Action Theory.

Maciej Bernasiewicz - doktor habilitowany, adiunkt w Katedrze Pedagogiki Społecznej Wydziału Pedagogiki i Psychologii Uniwersytetu Śląskiego w Katowicach. Autor książek: Yuppie oraz squatter. Globalne style życia w lokalnych środowiskach wychowawczych (Katowice 2013); Interakcjonizm symboliczny $w$ teorii i praktyce resocjalizacyjnej (Kraków 2011); Młodzież i popkultura. Dyskursy światopoglądowe, recepcja i opór (Katowice 2009). Adres do korespondencji: Uniwersytet Śląski w Katowicach, Wydział Pedagogiki i Psychologii, ul. Grażyńskiego 53, 40-126 Katowice. Adres e-meilowy: maciej.bernasiewicz@us.edu.pl. 